\title{
Commentary: Reflections on resilience in the Karamoja Cluster over 40 years
}

\author{
Darlington Akabwai
}

Dr. Darlington Akabwai has worked with Tufts University for 25 years on issues of pastoralism in East Africa. A veterinarian by training, he accepted his first appointment as a government veterinary officer in 1972 and was based in Moroto covering Central and South Karamoja Districts. He was promoted to District Veterinary Officer in North Karamoja in 1973. In 1975, he became the Officer in Charge at the Mbarara Government Dairy Farm. In 1977, he undertook a year-long course of study at the International Agricultural Center in The Netherlands. He returned to the Karamoja Cluster in 1978 (see discussion and Figure 1 in Catley et al. 2021 this Issue) with a job on a livestock improvement project with the Kakuma Catholic Mission Parish in Kenya. In 1980, he began to work with the European Economic Commission Rehabilitation Project, which became the Turkana Rehabilitation Project (TRP) and was designed to help the Turkana region in Kenya recover from the drought and famine of 1980. He worked with the TRP until 1987, focusing on assisting local herders to learn techniques of improved livestock management and disease control. Dr. Akabwai began working with American universities in 1992 on projects funded by Organization of African Union/Interafrican Bureau for Animal Resources (OAU/IBAR). In 1995, he started his long tenure at Tufts University and has spearheaded much of the Feinstein International Center's work in the region. These remarks are an edited version of his keynote speech at the "Pathways to Resilience" event.

I have worked in the Karamoja Cluster for over 40 years. There is a lot to say, but I will highlight a few activities that I felt worked positively for the resilience of

Correspondence: dakabwai10@gmail.com

Lodwar, Kenya the inhabitants of the Karamoja Cluster. I will then list what has changed over time and offer some recommendations for improving resilience in the Karamoja Cluster.

\section{Strategies for improving resilience among pastoralists and agro-pastoralists in the Karamoja Cluster}

Much of the Karamoja Cluster is characterized by arid and semi-arid conditions and receives $300 \mathrm{~mm}$ or less rain per annum. Precipitation is seasonal but very highly erratic in timing, volume, and distribution. The livestock-keeping communities living in the Karamoja Cluster are careful resource managers and have evolved a range of strategies to adapt to, rather than change or damage, the environment in which they live. These strategies include seasonal mobility, splitting herds, keeping several livestock species, and supplementing food and income with small-scale rain-fed cultivation, fishing, trading, and collection of wild foods.

\section{Shared and designated corridors and migratory routes}

A corridor can be defined as a geographical point of entry between any two tribal or ethnic groups, for example the area of land between the Dodoth of Uganda and the Turkana of Kenya (Kalapata- Camion on the Uganda side and Oropoi- Nawonitos on the Kenya side). These corridors have existed for centuries and allow for successful sharing of pasture, water, salt links, and other resources. Such a corridor is a critical zone which communities may be able to deliberately reserve as a place to fall back to when drought becomes severe, although such cooperation is only possible when groups are at peace. When peace does prevail, these corridors also often serve as places where the neighbouring communities can come together to share pasture and water, gather fruits, perform rituals, and engage in trade. In regard to pastoral livelihoods, these are vital passages

(c) The Author(s). 2021 Open Access This article is licensed under a Creative Commons Attribution 4.0 International License, which permits use, sharing, adaptation, distribution and reproduction in any medium or format, as long as you give appropriate credit to the original author(s) and the source, provide a link to the Creative Commons licence, and indicate if changes were made. The images or other third party material in this article are included in the article's Creative Commons licence, unless indicated otherwise in a credit line to the material. If material is not included in the article's Creative Commons licence and your intended use is not permitted by statutory regulation or exceeds the permitted use, you will need to obtain permission directly from the copyright holder. To view a copy of this licence, visit http://creativecommons.org/licenses/by/4.0/. 
where the livestock of one community can safely transit after having been granted grazing rights on the neighbour's side of the border. This shared system is supervised by the elders and the seers from both sides who seek to ensure peaceful sharing of natural resources, although periods of both sporadic and protracted conflict also characterize these locations. Elders often place the blame for such outbreaks upon young men whom they view as being inclined to break the peace by stealing animals. I have personally located myself along these various corridors of the Karamoja Cluster, vaccinating cattle of these communities, and we have conducted crossborder peace meetings and women's peace crusades since1972.

The ethnic groups in Karamoja (Uganda) strive to manage dry season access to resources by following designated migratory routes. These routes are groupspecific, which means that there is a route for the Bokora to Teso, for the Matheniko to Teso, for the Pian to Teso and Bugisu, for the Jie to Acholi and Lango, and, finally, for the Dodoth to Acholi and Didinga. Aside from the Dodoth routes, the Karamojong routes mainly follow riverbeds that start at the Karamoja escarpment and flow down to the plains of Teso and Acholi. Hence the statement from the Karamojong that "they follow their waters".

During the colonial period and the first two decades of independence, the Karamojong migrations were generally amicably received by their neighbours, in part because these neighbours received official protection from the government. The Karamojong and hosts shared resources, including the labour of female Karamojong in exchange for food provided by their Teso, Langi, and Acholi hosts. However, this relationship turned sour in 1980s when the security vacuum allowed the Karamojong to pillage the livestock of communities to the west (Knighton 2005). Raids in the 1980s drove the estimated cattle population in the raided areas from 685,000 in 1980 to only 72,000 in 1989 . At the same time, cattle numbers in Karamoja increased by an estimated 692,000 animals (Office of District Veterinary Officer 1989). Coming myself from Teso region, I remember our people in particular losing a large number of cattle to Karamojong raids, and we viewed the lack of effective government security as making this issue become a driving factor in the Teso rebellion against the central government, which ended in 1993. The experiences of insecurity by neighbouring regions led to political pressure on the central government and the eventual resumption of disarmament campaigns that started in the early 2000s. However, uneven disarmament contributed to widespread internal insecurity in the Karamoja region in the 2000s and raids exacerbated inequity of livestock ownership. Today, nearly 10 years after the government declared the successful removal of guns from the region, many Karamojong face severe livelihood challenges and poverty (Stites and Akabwai 2009).

\section{Livestock disease control}

The livestock corridors described above are where I focused on rinderpest vaccination, contributing to its eradication in 2010. In these unique areas, I met my target clients: pastoralists in Turkana, Toposa, and Nyangtom and agro-pastoralists from Karamoja. As it is also along the corridors that cattle raiding occurs, we had to conduct cross-border peace meetings and women's peace crusades to reconcile the warring parties and give us a conducive environment to treat their livestock. The peace building and vaccination work are in fact the two activities that I am most proud of since they contributed to the improvement of resilience of my clients.

The conventional approach to rinderpest vaccination involving qualified veterinary and livestock production staff proved challenging in Karamoja due to the harsh environment, difficult terrain, limited roads, and mobile herds. Rampant raids and civil wars in Uganda, Sudan, and Ethiopia made the situation worse and accounted for many of the delays in controlling rinderpest. Meanwhile, our medical colleagues were celebrating the eradication of smallpox globally in1980.This ignited our determination as veterinarians to work harder to make sure we vaccinated as many cattle as possible so as to improve the chances of control and eventual eradication of rinderpest.

Due to the difficult situation in the Karamoja Cluster, we were forced to think outside the box. We decided to introduce the livestock owners themselves into the vaccination programme and to join the few veterinary doctors who could reach the region. In 1992-1993 our team was comprised of veterinarians under the Organization of African Union/Interafrican Bureau of Animal Resources (OAU/IBAR) who were working closely with the government veterinary services of Kenya, Uganda, Tanzania, and Ethiopia. We operated a small unit called the Community-based Animal Health and Participatory Epidemiology Unit CAPE (Feinstein International Center 2019). This unit targeted and involved the herders in the treatment of their animals. We were further blessed by the discovery of a thermostable rinderpest vaccine, which solved the challenge of maintaining a cold chain in a poor terrain without access roads. Thermostable rinderpest vaccines were manufactured in commercial quantities in Botswana, and so the combination of community-based animal health workers (CAHWs) and the vaccine helped us to vaccinate thousands and thousands of cattle across the Karamoja Cluster.

While my expatriate colleagues were operating from Nairobi, I and other African veterinarians were stationed 
in Lokichogio, Kenya. From there, we would regularly fly to the interior of southern Sudan and use Land Cruisers to transport vaccines and staff. We were working on the frontline of the ongoing civil war at the time. My specific role in southern Sudan was to train the herders to help in the vaccination of their own herds. These trained herders were the paraprofessional staff who later became called CAHWs. We asked elders to select disciplined sons and daughters to be given intensive 3 to 4 weeks of training on rinderpest vaccinations. These young people turned out to be key staff in knocking out rinderpest in the remote and inaccessible areas of the Karamoja Cluster, because they know their ecosystem so well. Using this approach, we vaccinated hundreds of thousands of cattle in southern Sudan, such that reported cases of rinderpest reduced drastically even in conflict-affected areas.

Our team in Nairobi realized that although we had scored very well working in the battle fronts of southern Sudan, other parts of Eastern Africa were still reporting outbreaks of rinderpest. In 1997, we decided to move on to Moroto, Lodwar, and Kapenguria (in or near the Cluster), where we trained CAHWs. The vaccination campaign against rinderpest improved fantastically in these difficult regions through the use of our community-based system. In 1999, the Commissioner of OAU/IBAR was so happy with my contribution to rinderpest control that he gave me a certificate of recognition.

\section{Cross-border peace meetings in the Karamoja Cluster}

The enduring efforts on rinderpest were happening against a backdrop of cattle raids. This prompted a Turkana seer called Ekeno Loirabok to request me to help him to meet with his counterpart from the neighbouring Toposa grazing area. Ekeno told me, "Longechel (man with a gap in the upper teeth), you will only control rinderpest disease if you bring to me the elders of Toposa so that we can meet and talk about peace". I discussed in detail the situation with my colleagues at CAPE Unit and we went ahead to facilitate the first cross-border meeting between Toposa elders and warriors and Turkana elders and warriors. The meeting took place in Lodwar, Kenya, from March 30 to April 1, 1999, and was opened by the Turkana District Commissioner. The two ethnic groups were happy that they had at last agreed to live in harmony along their LokichogioNadapal corridor and many saw Toposa dancing together with Turkana for the first time (Organization of African Unity/Interafrican Bureau for Animal Resources 1999). A month later, we brought the same participants to Lokichogio to follow up on the points of agreements from the Lodwar Peace Meeting. Apart from minor mistakes of theft by the youth of either side, the elders reported that the peace had remained intact in the interim period.

Given that the acts by the youth had the potential to threaten the peace, the elders requested that even their stubborn sons be brought to Lokichogio to learn from these meetings. Hence, we mobilized the youth in each corridor and organized the first youth cross-border peace meeting. This was a unique peace meeting because we discovered that the two groups of participants already knew each other very well. They started by quarrelling to the point of fighting. The episode shocked us as facilitators, but the presence of the security officers gave us the confidence to watch the interactions in silence. After expressing their anger with abuses and fistshaking, the youth then turned to be very friendly and started narrating their past stories with joy! They were then given goats to roast and share together and that evening engaged in their traditional dancing, which helped to remind them that the Toposa and Turkana have a shared culture and language. Unlike their elders, they made very honest and practical recommendations for sustaining the peace. One of the most important suggestions was to involve their mothers in peace-making, as they said it was their mothers-more than their fathers-who were inciting them to raid. The young men said that their mothers wanted them to raid cattle to raise bride wealth: "that is what sends us to go and raid and get bridewealth or get killed! All is the same to them!"

This suggestion led to the first cross-border peace meeting between Toposa and Turkana women from the Lokichogio-Nadapal Corridor, and the meeting proved to be the most dramatic meeting I have ever facilitated in my conflict resolution work. The 40 women in attendance started by pelting me with questions. "Longechel (meaning me), why did you bring us here to Lokichogio?" When I replied that it was their sons who recommended that they attend this meeting, the mothers went wild, blaming the Ngorokonyang (Toposa raiding youth) and Ngigumakeri (Turkana raiding youth) for creating insecurity in the grazing areas. The women said:

They rape us when they get us collecting wild fruits; they molest us when they get us collecting firewood or water. And yet they are the ones who have made such recommendations about their mothers!...Since when did these youth see us with guns?...Longechel,(meaning Dr.Akabwai) if you are the one who has brought us here, please change this venue. We would like to take our Alokita [pressure group for the pastoralist women] to the grazing areas and watering points of Toposa, and Turkana, We want to take our Alokita to the tree of men where their 
fathers are regularly meeting. We would like to talk and sing our songs of sorrow to the elders and the chiefs of Toposa and Turkana and we have messages for the Ngorokonyang (Toposa raiding youth) and the Ngigumakeri (meaning the raiding Turkana raiding youth) and their Toposa and Turkana mothers.

This unique request turned out to be very expensive. It would require multiple vehicles to transport the women, a mobile kitchen, and 2 weeks of time to cover all the grazing areas and watering points. It was a relief when the CAPE Unit agreed to fund the first women's crusade in July 2001 (Akabwai 2001). The crusade was successful in its mission: the youth heard the messages from their mothers, the elders got it clearly from the mothers of their sons, and the seers on both sides heard their message, as did the chiefs and other administrators. Even the women themselves were told to be content with whatever cattle they had: "Stop sending your sons to die because of cattle. The few that you have now will multiply", said the crusaders.

Despite the high cost of the peace crusade approach, the CAPE Unit managed to fund a series of crusades from 2001 to 2004 and covered all the corridors of the Karamoja Cluster, including up to East Pokot. The impact of the peace crusades was to lower tensions, which allowed for concentrating on rinderpest vaccination, facilitating the eventual rinderpest eradication in 2010 .

\section{Concluding remarks}

In general, the cross-border peace-building activities which were conducted along the corridors of the Karamoja Cluster improved sharing of resources and made rinderpest vaccinations possible. In Karamoja (Uganda), these events, when added to the removal of guns through disarmament, have helped to expand development sector activities and trade. For example, the nowpeaceful corridor around Lokiriama, Kenya, is now booming due to the Moroto-Lodwar beer trade. The livestock market in Kotido is used by traders from across the region and has boosted trade in livestock. These and other improvements have positively impacted the resilience of the people of Karamoja.

However, there are also factors that have had negative impacts on resilience. These include the occasional lack of supportive involvement in peace-building by local politicians, human rights abuses in the name of disarmament and particularly the torture of male youth, widespread loss of livestock due to the protected kraal policy during which security forces openly steal recovered animals, on-going theft, increased inequity, lack of access to adequate veterinary care, environmental destruction due to the heavy tree cutting and charcoal burning, and efforts by district and national authorities to promote sedentarization of mobile pastoralists.

I have at times heard external actors and people of Karamoja comment that the international community has had no impact in the sub-region. My experience definitely contradicts this perspective. Rinderpest was eradicated, with great improvements for livelihoods. Cattle raids largely stopped due to the removal of the guns-I hope they do not resume. There is a much greater emphasis on education of children, and there is a growing Karamojong elite. Access to modern health care is also much improved. Tarmac roads from Soroti to Moroto and from Moroto to Nakapiripirit have opened the region to trade. Mineral wealth in the region is generating income, though it is unclear if common people will benefit from this or be cursed by it.

Lastly, some recommendations are based on my experience in the Karamoja Cluster. Restocking programmes should be run by civilians, not the military. The government should embrace rather than shun nomadic pastoralism and introduce pro-pastoral policies. Karamoja's regional neighbours to the west should be encouraged to accept the mobility of Karamojong herds. Cross-border trade, including in livestock, should continue to be encouraged. Mobility corridors for people and herds should be promoted and protected. Efforts should be put in place to limit the charcoal trade. While many other challenges remain for the populations of the region, the population and scholars from the Karamoja Cluster may be able to solve them with support!

Thanks for reading

Darlington Akabwai

\section{Acknowledgements}

The Pathways to Resilience in Karamoja conference and this Special Issue of Pastoralism were funded by USAID/Uganda, UKaid, and Irish Aid under

USAID contract 617-15-000014 to Tufts University for the Karamoja Resilience Support Unit.

Author's contributions

Sole authorship. The author read and approved the final manuscript.

\section{Funding}

USAID/Uganda, UKaid, and Irish Aid under USAID contract 617-15-000014 to Tufts University for the Karamoja Resilience Support Unit.

Availability of data and materials

The paper is a commentary and uses no data.

\section{Declarations}

Ethics approval and consent to participate

The research did not involve human subjects.

Consent for publication

The paper contains no individual's personal data.

Competing interests

There are no competing interests. 
Received: 24 September 2021 Accepted: 27 September 2021

Published online: 24 November 2021

\section{References}

Akabwai, D. 2001. The Turkana-Toposa-Nyang'atom-Didinga Alokita: The July Women's Peace Crusade. Nairobi: African Union/Interafrican Bureau for Animal Resources.

Catley, A., Stites, E., Ayele, M., Arasio, R.L. 2021. Introducing pathways to resilience in the Karamoja Cluster, Pastoralism: research, policy and practice (this issue) Feinstein International Center (2019). Community Animal Health and Participatory Epidemiology https://fic.tufts.edu/research-item/community-animal-health-a nd-participatory-epidemiology-cape/ (Accessed 1 Apr 2019)

Knighton, B. 2005. The vitality of the Karamoja religion -Dying tradition or living faith? Hants: Ashgate Publishing.

Office of the District Veterinary Officer. 1989. Protected Kraals Livestock Assessment Report, Moroto District. Moroto: Government of Uganda.

Organization of African Union/Interafrican Bureau for Animal Resources. 1999. Report of the cross border meeting between Toposa and Turkana at Nawoitorong, Lodwar. Nairobi: Organization of African Union/Interafrican Bureau for Animal Resources.

Stites, E., and D. Akabwai. 2009. Changing roles, shifting risks: Livelihoods impacts of disarmament in Karamoja. Uganda: Feinstein International Center, Tufts University, Medford.

\section{Publisher's Note}

Springer Nature remains neutral with regard to jurisdictional claims in published maps and institutional affiliations.

\section{Submit your manuscript to a SpringerOpen ${ }^{\circ}$ journal and benefit from:}

- Convenient online submission

- Rigorous peer review

- Open access: articles freely available online

- High visibility within the field

- Retaining the copyright to your article

Submit your next manuscript at $\boldsymbol{\nabla}$ springeropen.com 